\title{
Livelihood, Food and Nutrition Security in Southern Africa: What Role Do Indigenous Cattle Genetic Resources Play?
}

\author{
Obvious Mapiye $^{1}$, Obert C. Chikwanha ${ }^{1}{ }^{\mathbb{D}}$, Godswill Makombe ${ }^{2}$, Kennedy Dzama $^{1}$ and \\ Cletos Mapiye ${ }^{1, *}$ \\ 1 Department of Animal Sciences, Faculty of AgriSciences, Stellenbosch University, Stellenbosch 7600, \\ South Africa; 19645309@sun.ac.za (O.M.); occhikwanha@yahoo.com (O.C.C.); kdzama@sun.ac.za (K.D.) \\ 2 Gordon Institute of Business Science, University of Pretoria, Lynnwood Rd, Hatfield, Pretoria 0002, \\ South Africa; makombeg@yahoo.com \\ * Correspondence: cmapiye@sun.ac.za; Tel.: +27-21-808-2640
}

Received: 31 October 2019; Accepted: 4 February 2020; Published: 12 February 2020

\begin{abstract}
Of the 345 million people in the Southern African Development Community (SADC), 30.6\% are severely food insecure, $8 \%$ malnourished and $50 \%$ live with less than US $\$ 1$ per day, respectively. Livelihood, food and nutrition security have, therefore, become key priorities for the SADC region in response to these complex challenges. Given that $70 \%$ of the SADC population directly rely on agriculture for food, nutrition and income, sustained agricultural productivity may play an important role in achieving livelihood, food and nutrition security in the region. Being an important part of the agri-food system of marginalised communities in the region, cattle have great potential to contribute to the goal of reducing food and nutrition insecurity. The region has a population size of about 64 million cattle of which $75 \%$ of the population is kept under the smallholder farming systems, and primarily composed of indigenous tropical breeds. Most indigenous cattle breeds are, however, either undergoing rapid genetic dilution or at risk of extinction. At the same time, their environments, production and marketing systems are experiencing high rates of change in time and space. More importantly, indigenous cattle breeds in the region are undervalued. This makes it uncertain that future systems will have the adapted cattle breeds required for optimal livelihoods, food and nutrition security. To this end, the promotion of sustainable use of indigenous cattle for livelihood, food and nutrition security in the SADC region is strongly recommended.
\end{abstract}

Keywords: cattle; food; income; indigenous breed; nutrition; SADC; sustainability

\section{Introduction}

Food insecurity is one of the greatest challenges in the Southern African Development Community (SADC) as envisaged through hunger, malnutrition and poverty [1]. Of the total SADC population of approximately 345 million, about one-third is severely food-insecure, one-tenth is undernourished [2] and half live on less than US $\$ 1$ a day [3]. In this context, achieving livelihood, food and nutrition security are key priorities for the SADC region [1]. The definitions and concepts of "food and nutrition security", and "livelihoods" have evolved and expanded over the recent decades and are still subject of debate $[4,5]$. Food and nutrition security is defined as a condition that "exists when all people at all times have social, economic and physical access to food of sufficient quantity and quality in terms of variety, diversity, nutrient content and safety to meet their dietary needs and food preferences for an active and healthy life, coupled with a sanitary environment, adequate health, education and care" [6,7]. Livelihoods refers to "secure ownership of, or access to; resources and income earning 
activities, including reserves and assets, to offset risks, ease shocks and meet contingencies" [8,9]. Although the definitions and concepts of "food and nutrition security" and "livelihoods" can be internationally accepted, it is important to develop local or region-specific indicators for these terms as opposed to universal ones.

In the SADC region, about $70 \%$ of the population directly depend on agriculture for food, nutrition and income [1]. In that regard, sustained agricultural performance plays a significant role in increasing food and nutrition security and therefore contributing towards livelihoods in the region. Livestock constitute an important natural resource for the SADC region, with over $60 \%$ of the region's total land area being suitable for grazing [10]. Cattle with a population size of 64 million are among the most important livestock species [11]. Of the total cattle population in the region, $75 \%$ are raised on rangelands under the smallholder farming sector [11]. Indigenous tropical cattle breeds are the most dominant in the SADC region [11,12]. The region has about 40 indigenous breeds, which are broadly classified into two categories: Bos indicus or Zebu (e.g., Angoni, Madagascar Zebu, Malawi Zebu and Zanzibar Zebu) and B. taurus africanus or Sanga (e.g., Ankole, Nguni, Tswana and Tuli) [12,13]. Over the past four centuries, there has, however, been a decline in the population sizes of indigenous tropical breeds as a result of farmers' preference for fast-growing and large-framed exotic temperate breeds [12,14]. This has led to an increase in the number of non-descript crossbred cattle, especially in the smallholder areas where mating is often uncontrolled [11]. Consequently, the genetic diversity within and among indigenous tropical breeds and indigenous knowledge systems associated with them is currently being eroded $[15,16]$. If this continues, indigenous cattle's multiple and diverse economic and social-cultural roles, ecosystem services [12,17,18], and their contributions to livelihood, food and nutrition security may soon be lost in time and never be recovered.

Overall, indigenous cattle genetic resources in Africa are undervalued, and the awareness about their uses and values is limited [15]. It is, therefore, important to document the roles of indigenous cattle and highlight their contributions to food, nutrition and livelihoods, and account for them in policy and legal frameworks at national and regional levels. The significance of roles and contributions to livelihood, food and nutrition security can vary between environments and in time owing to the rapidly changing demographics, production systems, climate, technologies, consumer habits and lifestyles, policies and institutions [19]. In that regard, the roles and contributions of indigenous cattle to livelihood, food and nutrition security continues to be a subject of significant review and debate. In the context of this review, indigenous tropical breeds refer to the Bos indicus and B. taurus africanus (an admixture of $B$. indicus and B. taurus) found in the SADC region, while exotic temperate breeds refer to $B$. taurus cattle exclusively bred and imported from the temperate regions. The current paper documents the past, present and potential future roles of indigenous cattle and highlight their contributions to livelihood, food and nutrition security in the SADC region.

\section{Contributions of Indigenous Cattle Genetic Diversity to Livelihood, Food and Nutrition Security}

The greatest asset of indigenous cattle lies in their unique adaptive characteristics owing to the genetic diversity among the breeds $[15,18]$. This is important given that the majority of resource-poor smallholder farmers who are the owners of these indigenous breeds reside in marginal environments prone to natural disasters such as droughts, disease and parasite manifestations [1]. Overall, high-yielding exotic temperate breeds have failed to adapt to such harsh tropical environments because they have been selected for productive traits over many decades in temperate environments [15]. It should be noted that natural selection is important for breeds to become adapted to changes in environment and time, however, small and/or declining populations threaten this process [20]. Indigenous tropical breeds have undergone selection over centuries under harsh environmental conditions and, therefore, often have better foraging ability, heat tolerance, disease and parasite resistance than the exotic temperate breeds $[15,18]$. For example, the Nguni breed has been reported to have lower nematode infestation levels [21], tick counts [22-24] and seroprevalence 
for Anaplasma marginale and Babesia bigemina [25], and utilise fibrous forages better [26-28] than exotic temperate breeds and/or their crosses with indigenous tropical breeds. In that regard, their lifetime contribution to livelihood, food and nutrition security could outweigh that of exotic temperate breeds due to their ability to utilise marginal environments (i.e., superior adaptability, fertility and longer longevity, ability to walk long distances and survive long periods without water) [15]. Furthermore, for farmers willing to improve economic efficiency, indigenous cattle breeds can be used in sustainable crossbreeding programmes with exotic temperate breeds [29]. For example, Mokolobate et al. [30] reported a $21 \%$ increment in cow productivity ( $\mathrm{kg}$ calf weaned per Large Stock Unit) through sustainable crossbreeding program between Afrikaner cows with either the Brahman, Charolais, Hereford and Simmental bulls. Indigenous breeds can also be used to develop high-performing and adapted synthetic breeds, such as the Musi beef breed of Botswana, which is comprised of $28.24 \%$ Tswana, $4.44 \%$ Tuli, 26.32\% Simmental, 22.60\% Brahman and 18.40\% Bonsmara [15]. Crossbreeding could also be practiced between indigenous tropical breeds (e.g., Zebu and Sanga breeds) from similar environmental conditions to retain the adaptive attributes. Indigenous cattle are an important reservoir of genetic diversity that may be used for current and future production of new and self-sustainable breeds since most of them have superior adaptive traits compared to highly productive exotic temperate breeds. In that context, indigenous cattle breeds offer resource-poor smallholder farmers a variety and variability of genetic material to meet current and future livelihoods, food and nutrition demands in tandem with consumer preferences and changing economic and environmental conditions [18,31]. However, African farm animal genetic resources, including indigenous cattle, are undervalued, and they are either undergoing rapid genetic dilution or are at risk of extinction [10,15]. This has renewed interest and awareness regarding the genetic diversity of indigenous cattle because of their potential economic and socio-cultural benefits and ecosystem services [15,32].

\section{Economic Contributions of Indigenous Cattle to Livelihood, Food and Nutrition Security}

Most rural people in Southern Africa depend mainly on crop and livestock farming as sources of livelihood, food and nutrition [1]. In sub-Saharan Africa, crops contribute over $60 \%$ energy of food availability [33]. Although cattle contributes less energy than crops, they strongly influence food and nutrition availability through the complex crop-livestock farming system interactions [33]. For example, cattle provide manure and draught power for cropping whilst crop residues provide feed to cattle. The economic contributions of cattle to livelihood, food and nutrition security are direct through provision of food (i.e., beef, milk and blood) [34,35] or indirect through cash income from sales of live cattle and their products, which is used to purchase food and/or other household needs [36-38]. The total economic contributions of cattle are, however, frequently underestimated as some outputs are often intangible and typically not recognised by markets [10,39]. Draught power and manure, for example, are not final outputs, but inputs to crop production which are utilised mainly within the households owning the cattle [36]. Yet, it is unusual for monetary value to be ascribed to these inputs. Products from the cattle can be divided into flow (e.g., milk, draught power and manure) and end products (e.g., beef, offals, horns, skins and hides). Flow products are obtained and used during the lifetime of an animal, whereas the end products are obtained peri- or post-mortem [40]. Most smallholder farmers prefer the former since sales or slaughter of the animal entails the permanent loss of flow products [40]. Cattle products can be processed into several by-products such as buttons from horns, musical instruments, mats or footwear from hides.

\subsection{Beef}

Meat, including beef, is a significant component of the human diet with generally positive implications on health, economy, culture and environment [41-43]. Beef directly contributes to food and nutrition security through provision of energy (i.e., fat), high-biological-value protein, essential amino acids, unsaturated fatty acids (i.e., vaccenic acid, rumenic acid and omega-3 fatty acids), minerals (i.e., iron, copper, zinc, selenium and phosphorus) and vitamins (i.e., thiamine, niacin, riboflavin, 
cyanocobalamin and retinol) [44]. It is also an important source of a range of endogenous antioxidants and other bioactive substances including taurine, carnitine, carnosine, ubiquinone, glutathione and creatine with human-health benefits [45]. Relative to B. taurus (i.e., mainly temperate breeds, e.g., Aberdeen Angus), B. indicus (e.g., Malawi zebu) or B. taurus africanus breeds (e.g., Nguni) have lower carcass yields and dressing percentage, comparable meat colour and nutrient composition, and healthier fatty acid profiles (Table 1). Beef tenderness is comparable between B. taurus africanus and exotic temperate breeds but relatively low for the B. indicus breeds (Table 1 ). The tougher meat of $B$. indicus could be ascribed to lower carcass weights coupled with leaner carcasses, leading to greater muscle shortening under a fast chilling regime and slower rate of post-mortem ageing due to higher muscle calpastatin activity [44,46]. However, there is a segment of consumers in Southern Africa that prefer less tender, juicier and flavoursome meat from older cattle finished on rangelands, especially among black African communities [47,48].

Table 1. Selected cattle performance, beef quality and fatty acid profiles.

\begin{tabular}{|c|c|c|c|c|}
\hline Parameter & Nguni ${ }^{a, c}$ & Malawi Zebu ${ }^{\text {b }}$ & Bonsmara $^{c}$ & Aberdeen Angus $^{c}$ \\
\hline Average daily gain $(\mathrm{kg} / \mathrm{d})$ & $0.20-0.38$ & $0.83 \pm 11$ & $1.83 \pm 16.6$ & $1.98 \pm 19.4$ \\
\hline Slaughter weight $(\mathrm{kg})$ & $205-295$ & $241 \pm 12.3$ & $255 \pm 6.8$ & $240 \pm 8.0$ \\
\hline Cold carcass weight (kg) & $107-170$ & $119 \pm 6.17$ & $145 \pm 3.7$ & $129 \pm 4.4$ \\
\hline Dressing percentage & $52.1-56.3$ & $50.4 \pm 0.58$ & $56.9 \pm 0.78$ & $53.7 \pm 0.92$ \\
\hline \multicolumn{5}{|l|}{ Meat proximate (\%) } \\
\hline Moisture & $76.2-77.4$ & $72.2 \pm 0.77$ & $77.7 \pm 0.13$ & $77.7-77.9$ \\
\hline Protein & $21.0-22.5$ & $22.3 \pm 0.62$ & $20.6 \pm 0.12$ & $20.0-20.4$ \\
\hline Fat & $0.87-1.21$ & $1.80 \pm 0.45$ & $0.79 \pm 0.08$ & $0.76-1.18$ \\
\hline Ash & $1.07-1.80$ & $1.20 \pm 0.07$ & $1.07 \pm 0.01$ & $1.06-1.07$ \\
\hline \multicolumn{5}{|l|}{ Meat colour } \\
\hline Meat lightness $\left(\mathrm{L}^{*}\right)$ & $36.5-38.2$ & $39.6 \pm 1.65$ & $38.6 \pm 0.52$ & $39.9 \pm 0.62$ \\
\hline Meat redness $\left(a^{*}\right)$ & $15.5-15.8$ & $12.6 \pm 0.94$ & $16.0 \pm 0.39$ & $16.6 \pm 0.47$ \\
\hline Meat yellowness $\left(b^{*}\right)$ & $6.5-7.4$ & $7.73 \pm 1.11$ & $6.7 \pm 0.21$ & $7.1 \pm 0.25$ \\
\hline $\begin{array}{l}\text { Meat tenderness (WBSF }{ }^{d} \text {, } \\
\text { Newtons) }\end{array}$ & $39.2-61.8$ & $41.2 \pm 4.9$ & $46.1 \pm 3.82$ & $37.2 \pm 4.51$ \\
\hline \multicolumn{5}{|l|}{ Fatty acids (\%) } \\
\hline Oleic acid & $28.9-31.8$ & - & $29.9 \pm 0.60$ & $31.1 \pm 0.94$ \\
\hline Vaccenic acid & $1.28-1.39$ & - & $1.40 \pm 0.18$ & $1.74 \pm 0.28$ \\
\hline Rumenic acid & $0.34-0.39$ & - & $0.31 \pm 0.03$ & $0.33 \pm 0.05$ \\
\hline Linoleic acid & $2.41-5.44$ & - & $2.49 \pm 0.13$ & $2.21 \pm 2.08$ \\
\hline Alpha-linolenic acid & $1.53-2.41$ & - & $2.48 \pm 0.13$ & $2.20 \pm 0.21$ \\
\hline Eicosapentaenoic acid & $1.60-1.95$ & - & $2.04 \pm 0.15$ & $2.00 \pm 0.23$ \\
\hline Docosahexaenoic acid & $0.10-2.64$ & - & $2.57 \pm 0.19$ & $2.43 \pm 0.30$ \\
\hline
\end{tabular}

Source: ${ }^{\mathrm{a}}$ [49-54]; ${ }^{\mathrm{b}}$ [55]; ${ }^{\mathrm{c}}$ [56]. Note: data shown as ranges was obtained from different studies $\left({ }^{\mathrm{a}}\right.$ and $\left.{ }^{\mathrm{c}}\right)$, while mean \pm standard error of means was from single study. ${ }^{d}$ WBSF-Warner Bratzler shear force.

Generally, data on consumption patterns of meat at individual and household levels in developing countries is seldom collected [57]. Beef consumption within the SADC rural communities has, however, been reported to be low and seasonal [58,59], largely due to the multipurpose nature of cattle [60]. Cattle slaughter usually occur when an animal becomes sick or unproductive, or for exceptional occasions such as ceremonies or hospitality [37,38]. There is a risk of transmission of zoonotic diseases when meat from sick animals is consumed. The risks is common in areas where veterinary and extension services are absent, or farmers lack information on zoonotic diseases, and the poverty levels are high [61]. Household meat consumption is generally ranked below other uses such as cash income, asset saving and draught power [36,62]. Overall, current dietary recommendations to reduce the intake of red meat including beef for health and environmental reasons [63] could have devastating effects on poor communities who are both food and nutrition insecure. Recently, it has been argued that claims about the health issues (i.e., negative cardiometabolic outcomes and cancer mortality and incidences) of red meat are not only improbable in light of human evolutionary history, but are far 
from being supported by robust scientific evidence [42,43]. Similarly, claims about the devastating impact of red meat production on the environment ignore the essential role that grazing animals play in sustainable agriculture (e.g., biorecycling, soil fertilisation and biodiversity preservation) $[42,64,65]$. Therefore, recommendations must always be considered in a specific context, while in some western countries the reduction of meat consumption is recommendable, in many developing countries a higher consumption of products of animal origin is needed for a sustainable diet.

\subsection{Milk}

Bovine milk has long traditions in human food and nutrition. Unlike beef from cows, which is often an end product, usually after 10 years or more of on-farm productive use, milk, although limited, is available during the lactation lifetime of the animal. Milk is a source of high-quality protein and bioactive fatty acids, essential amino acids, magnesium, zinc, phosphorus, and calcium, retinol and cholecalciferol (vitamin D3) [66,67]. Zhang, Goldsmith, and Winter-Nelson [57] reported that consumption of small amounts of milk in Zambia enhanced the supply of essential nutrients, subsequently reducing the probability of their inadequacy among infants. In most SADC countries, there is a tendency of children being offered cow's milk during or immediately after milking $[68,69]$. In most rural economies, cow ownership has been observed to increase children's milk consumption, increase linear growth, and reduce stunting [70,71]. Overall, milk and beef provide critical and usually limiting nutrients (high-biological-value and more bioavailable) essential for health and development to vulnerable groups such as children, women of reproductive age, or the elderly [34,35]. Such assertions are supported by a study in Rwanda were monthly milk consumption per household and children's (under 5 years) height-for-age z-scores increased by 9.4 litres and 0.54 standard deviations, respectively, in households that received a dairy cow from the Heifer International's donation program [72].

Although milk has a variety of uses among the rural folks, it is primarily consumed either as fresh or fermented, with surplus being sold within the community [37]. According to Chagunda et al. [69], households owning lactating cows have a $58 \%$ greater chance of consuming milk and its by-products on a monthly basis compared to those without lactating cows. This is further supported by findings of Mapekula et al. [73] who reported that consumption of fresh milk were on average 1.5 and 2.6 litres/day per household among communal and small-scale farming areas, while that of fermented milk was 2.1 and 2.0 litres, respectively. Overall, data on the milk production and consumption in rural areas within the SADC region is scarce, and its contribution to the household and national economies is largely unknown [73].

Indigenous cattle have not been solely bred for milk production but have been selected for adaptive traits enabling them to survive in marginal environments [32]. However, research has neglected indigenous cattle breeds in preference to exotic dairy breeds owing to their low milk yields [67]. The low milk yield challenge is, however, offset by their multipurpose nature, resilience and adaptability to the local environment $[37,67,73,74]$. Indigenous tropical breeds are the main source of milk in smallholder farming areas, but crosses and exotic temperate breeds are also available, albeit in small numbers [73,75-78]. In a study to compare the lactation performance of dairy cattle (indigenous, crossbreds and exotics) under smallholder management (i.e., communal vs. small-scale commercial), Masama et al. [74] observed that total lactation yields were greater in the communal sector, irrespective of breed. This could have been due the longer lactation length in this sector, i.e., 399 versus 296 days in the small-scale commercial sector and the latter had fewer exotic cattle [74]. However, across the two production systems, the indigenous cows (i.e., Mashona) produced the lowest milk yield (i.e., 638-704 kg per lactation) compared to either crossbreds or exotic. Similarly, Maiwashe et al. [79] reported that the daily peak yields for the Bonsmara and Nguni were $10 \mathrm{~kg}$ and $7 \mathrm{~kg}$, respectively. Myburgh et al. [67] found that the nutrient composition (i.e., proximate and casein) of the indigenous tropical breeds was comparable to that of European beef breeds. Compared to other indigenous breeds, the Nguni had the greatest milk fat, while Tuli had the lowest content [67]. Use of heifers and cows as draught animals and the scarcity of feed are some of the reasons for the reported low milk yields [80]. 
Regardless of their low milk output, indigenous cows have a 10 to 15 -year reproductive life during which they drop 6 to 10 calves [73] and their lifetime benefits far outweigh that of exotic cows [81].

\subsection{Dung}

Irrespective of breed, a mature cattle produces an average of 4 to 9 tonnes of fresh dung per year [82,83]. Cattle dung can be processed for use as manure or energy (i.e., dry dung or biogas) production $[36,37,84]$. Manure is mainly used for soil fertility restoration (maintain or increase soil organic carbon content). This leads to increased porosity and potential reduction in traction energy used for soil tillage [85]. The decrease in draught force because of improved soil structure could reserve energy for production purposes. In addition to being an excellent source of organic matter $(250-267 \mathrm{~g} / \mathrm{kg})$, cattle manure is also a good source of soil nutrients such as nitrogen $(2-23 \mathrm{~g} / \mathrm{kg})$, phosphorus $(1.4-8 \mathrm{~g} / \mathrm{kg})$, potassium $(1.2-45 \mathrm{~g} / \mathrm{kg})$ and other micronutrients coming from animal diets [83,86-89]. According to Food and Agriculture Organization of the United Nations (FAO) [90], African cattle, irrespective of breed, produce $14.1 \%$ of the global nitrogen (i.e., 2005 estimates) from manure. It should be noted that manure chemical composition is largely influenced by diets and production system among other factors [88]. To our knowledge, there are no studies that have studied the effects of cattle breed on dung nutrient composition, and thus merit investigation. Use of cattle manure in plant production could save most of the poverty-stricken farmers from the cost of buying commercial fertilisers [91]. However, some farmers perceive manure as a supplement to inorganic fertiliser rather than a substitute [18]. This is because of its additional liming effects on soil [89], which may be due to calcium carbonates and organic acids in the manure that buffer soil acidity $[86,92,93]$. In addition, farmers add organic manure due to its ability to act as a biological agent for soil health improvement and productivity [18]. The greatest impact of manure is the return of part of the nutrients ingested to soils, both on the rangelands (as dung produced during the daytime deposited on the grazing or arable lands) and crop production (direct application from the kraal) $[37,64]$. Cattle dung contributes to food and nutrition security either through its sales or improving soil fertility and structure, which increases crops yields [84-86,93]. Cash from cow dung sales can be used to purchase household goods, including food. Furthermore, savings made by not purchasing inorganic fertilisers may also boost the family income.

In Southern Africa, cattle dung is mainly used as an energy source for cooking or heating, especially in deforested smallholder areas [94]. South Africa is one of the few countries in Southern Africa were small-scale biodigesters have been introduced $[95,96]$. Although, the uptake is low, as it is currently limited by input supply (i.e., livestock manure), its use could be beneficial, not only as a cheap energy source but also contribute to climate change mitigation through reduced deforestation [95]. Thus, reduce the high levels of land degradation caused by the cutting of trees for energy production.

\subsection{Draught Animal Power}

The interdependence between the crop and livestock farming is complex. On one hand, both enterprises compete for resources, such as land and labour. On the other hand, cattle provide traction and manure for crop production and use crop residues and by-products as feed [97]. Draught animals play an indispensable role in agricultural and transport sectors in SADC, especially on small farms. Globally, there has been a decrease in draught animal power usage as tractors have superseded this ancient tradition of farming [34,98]. Poor agricultural policies and the perception that animal traction is "archaic" has reduced focus and limited funding for the development of draught animal power [99]. Nonetheless, in SADC, this technology has remained fundamental, both for economic and agro-ecological reasons. The majority of poor people in SADC cannot afford the expensive fuel-powered tractor mechanisation (i.e., due to high initial cost of purchase, maintenance and operation), thus, rely on this eco-friendly technology that is based on renewable energy, which integrates the livestock and crop production systems $[100,101]$. In addition, sloped terrains (e.g., hillsides and steep valleys) 
and very small arable land sizes typical of most rural farms in the region makes it technically and economically unsustainable to use tractors [98].

Oxen are the dominant draught animals, but cows are also used when herd sizes are small [84,97]. Use of cows as draught animals, however, has a huge cost on growth, reproduction and milk yield [80]. Although exotic breeds can also be used as draught animal power, it is preferable to use indigenous tropical breeds because of their adaptability to the local environments. This relates to the delicate balance between the animal and stress-causing aspects (i.e., heat, diseases, parasites and low nutrition) of their environment. Draught animal power would further impose severe stress on exotic animals further disturbing the fragile balance with the environment in rural areas. The valuation of draught power from different breeds (indigenous, crossbreds and exotics) to determine which of breed provides sustainable draught power could be important.

Overall, the livelihood of cattle farmers is improved by utilisation of draught animal power as there would be increased crop yields through improved land preparation, deeper ploughing, quality and timeliness of operations, increased efficiency and reduced labour compared with manual alternatives [37,101-104]. Furthermore, there is a possibility of income generation by facilitating rural trade through on- and off-farm transport (i.e., distribution of farm input, such as fertilisers, seeds, crop protection requisites), and outputs (harvested crops and animal products)) [37,98,102]. Some farmers can either hire or rent draught animals for a certain period of times at a fee. The aforementioned outputs, therefore, contributes a lot towards ensuring livelihoods, food and nutrition security $[37,98,102]$.

In SADC, men are generally the owners of cattle, yet, women provide most of the manual labour; they are carriers of water, fuel wood, food grains and agricultural products, thus, use of draught animal power can benefit them directly [102]. Improved use of draught animal power in remote areas creates opportunities for empowering women and benefiting them economically [105] as they do not have to spend a lot of their energy on activities that can be done by draught animals, with more efficiency. There is evidence that women's improved access or control of assets has broad positive household welfare implications, as they are more likely to prioritise household needs with their spending patterns [106]. In that regard, promotion of draught power is one strategy that can be increasingly used to empower women and enhance household livelihood, food and nutrition security $[107,108]$.

\subsection{Other Products and By-Products From Cattle}

The slaughter of cattle generates other edible products (e.g., offals and blood) and non-edible unique products (horns, skins and hides). Liver, kidney, tongue and heart from cattle have comparable nutritional profile to beef with essential vitamins and amino acids, minerals and some bioactive polyunsaturated fatty acids [109]. Intestines, tongue, oxtail and hooves from indigenous cattle breeds are valuable delicacies for rural consumers. Therefore, consumption of such products could contribute significantly towards reduction of food and nutrition insecurity in the region. Blood is another end product which is consumed either fresh or boiled/cooked in other cultures. In Tanzania and the Democratic Republic of the Congo, for example, fresh blood is almost a staple food [110-112]. Fresh blood is directly obtained by making a small cut on the animal's jugular vein without killing the animal. It can be consumed as is or mixed with milk, and is a good source of iron, calcium and vitamin A [110]. In some Southern African countries, blood is collected at slaughter and boiled for consumption.

Non-edible products can be further processed into secondary by-products [109]. For example, Ankole's long, thick, and magnificent horns and Nguni's multi-coloured hides are processed into good-looking and long-lasting by-products [32] Cattle skins and hides contribute significantly to the gross domestic production of most countries, yet at household and community levels, no economic benefits from these products have been formally recorded [113]. If sales can be improved at household level through community-based programs [114], this could boost farmers income, that could be spent towards food among other household essentials. However, smallholder farmers still face challenges such as poor quality of raw materials (animals are diseased or skins damaged during provision of traction or slaughter) and lack of efficient market structures [114]. This is mostly attributed to the low 
off-take rates among smallholder farmers, hence the supply within the formal market is not guaranteed. Cattle hides derived from indigenous cattle ("Zebu" or "Sanga" type) are unique and popular for their fine grain pattern and fibre structure that are well suited to produce high quality upholstery. Hides have been used over the centuries to make clothing, carpets, bedding materials, footwear and musical instruments. Hides are also used to make harnesses, lead ropes, whips and strops for holding the yoke-pegs to the animal's neck.

\subsection{Income Generation}

Smallholder cattle farmers tend to sell rather than consume the beef they produce [34]. However, returns from sales of indigenous tropical breeds on the formal markets are low, owing to their light weights [115]. This is further complicated by the current beef carcass grading and classification systems in the region, which inappropriately values carcasses from slow-growing indigenous cattle breeds often finished on rangelands [11]. It would, therefore, be more appropriate to have a regional classification system that takes into consideration the ranking of carcasses according to meat quality attributes for quality assurance of both the producer and the consumer [115]. Based on the current beef prices (US \$2.53/kg carcass weight) [74] and carcass weight for a Nguni breed (Table 1), a farmer would receive between US \$271-396 in the formal market (i.e., licensed markets including abattoirs, processors, retailers, butcheries and restaurants) versus an average of US $\$ 793$ on the informal market (i.e., unlicensed market) [116] (exchange rate $=$ US \$1:R14.62). The majority of the rural farmers would thus forego selling their indigenous cattle through formal market and opt for the informal one where the prices are based on visual appraisal and negotiations [115,116]. In that context, the off-take rates of indigenous cattle from smallholder areas could, thus, be higher than the estimated $5-10 \%[58,59,117]$. Although indigenous cattle owners might get better returns from informal marketing, food safety regulations are not available or often poorly enforced and might compromise the health and well-being of the consumers. In this regard, the contribution of beef to food and nutrition security is indirect through sales of live cattle, their products and by-products to formal or informal markets. The cash income generated is used to cover household needs such as paying for education, healthcare, purchase of staple foods and farming inputs (seeds, manure and equipment), which can boost sustainable crop production in mixed crop-livestock systems $[34,37,38]$. The challenge is that most poor communities purchase foods that are starch-based, which can be deficient in one or more essential amino acids and vitamins, and thus fail to meet all their daily nutritional requirements [34]. The low levels of beef consumption among the poor people who own cattle is sometimes compensated by the availability of milk, which can be consumed without the need to slaughter or sell the animal $[35,118]$.

Milk consumption patterns have been shown to increase among dairy farmers and their neighbours as surplus is usually sold within the community [57]. In South Africa, for example, about 0.7 litres of fresh milk and 0.5 litres of fermented milk are sold per day per household [73] and one litre of fresh milk is sold on the informal market at R8.50 (US $\$ 0.58$ ). Considering that about one litre of milk is sold per day per household $[37,68,73,74]$, the overall cumulative monthly income per household, may be less than US \$20. Irrespective of the animal-derived sales, Enahoro et al. [35] concluded that increased ownership of farm animals and the subsequent household production is likely to result in greater household income. This may circumvent food and nutrition insecurity, and reduce poverty $[34,64,119]$.

Cattle manure value chains play important biological and economic roles in smallholder crop-livestock systems in developing countries, but relative to other livestock products current understanding of the nature and impact of manure sales is limited [120]. However, Randela [84] estimated the cost of manure to be US $\$ 0.04 / \mathrm{kg}$. Based on data by Yadav, Gupta and Garg [82], a mature cow produces about $5000 \mathrm{~kg}$ of dung annually, one animal would have returns of up to US $\$ 200 /$ year. However, not all the generated manure will be sold as most of the dung is used for the owner's cropping enterprise and some is used at household level (i.e., wall and floor plastering). Therefore, the income generated will be far less than we estimated as the maximum return. 
Okello et al. [99] estimated that draught power generates an average gross margin of US $\$ 45$ per animal annually. In South Africa, the cost of ploughing per draught animal per year was estimated at US \$38 (exchange rate US \$1:R6.89) [84]. The lower values for Randela [84] did not include hiring as most of the farmers only used their animals for ploughing cattle owner's fields. Although these values are based on estimates, they are quite comparable and can be based on fact that there are negotiated between supplier and client [84]. Income is also generated through use of draught animals to transport goods. Some farmers also sell trained draught animals to the other farmers at a premium price. Sale of pure indigenous breeds' genetic material for herd building and breeding purposes also generates cash income for the poor smallholder farmers. In some cases, indigenous cattle are used as a means of trade. Overall, cattle are transformative as cash income obtained through sales of live animals, animal products and by-products, transportation of goods and hiring of draught animals allow payment of food and other household needs. Owing to their adaptability to the marginal environments, indigenous breeds are more likely to produce optimal income for sustainable livelihoods, food and nutrition security in the region in future than their exotic counterparts.

\subsection{Employment}

Indigenous cattle farming creates more employment opportunities for rural communities in the marginal environments [1] than the non-adapted exotic temperate breeds. For example, various groups (e.g., herders, community-based agricultural extension agents, animal health workers and salespersons) are hired to carry out different duties relating to indigenous cattle production and marketing in the rural areas. Indigenous cattle products (e.g., milk, horns, skins and hides) are processed into a number of unique traditional and modern by-products that provide local people, particularly women and youth with employment and opportunities to establish small-scale animal product processing and marketing businesses [105]. Local jobs are also created through training of draught animals, transportation of goods and provision of animal traction to neighbouring farms for cash income [97]. Additional jobs are created through secondary enterprises associated with animal traction such as manufacturing of yokes, traction chains and ox-drawn implements (e.g., carts, ploughs, ridgers, planters, cultivators and harrows). Kraal construction, digging of manure from the kraal and spreading it in the fields are the other sources of cattle-based employment for the rural communities in the SADC region. Gathering and selling dried dung, and provision of biogas energy to the local community are also important sources of employment and business opportunities for the marginalised communities in the region [95]. In addition, employment is created through cultivation, harvesting, transporting and feeding of fodder for the animals. However, with the increase in mechanisation and the rise in urbanisation, some of the employment opportunities will be threatened as people may want to adopt the new technologies. It will be prudent for individual countries in SADC to promote and foster environments which are conducive for sustenance of rural livelihoods. For example, South Africa has developed a policy promoting sustainable livelihoods and decent work in rural areas, especially with greater emphasis on agriculture [121]. This is critical considering the high levels of poverty in the region [1]. In addition, the growing SADC population, will lead to an increase in the demand for animal protein, particularly low-value, low-processed livestock products [122]. Overall, these indigenous cattle farming-based employment and business opportunities will ultimately improve livelihood, food and nutrition security for the poverty-stricken communities in the region compared to non-adapted exotic counterparts.

\section{Socio-Cultural Contributions of Indigenous Cattle to Livelihood, Food and Nutrition Security}

In Southern Africa, indigenous livestock, particularly cattle are not only a means of survival but are also interwoven into diverse facets of people's everyday lives [123]. The way indigenous cattle are looked after displays the presence of a detailed connection among these animals, local people and their cultural beliefs [12,17]. This shows that apart from economic contributions, indigenous cattle have social significance and their roles embrace substantial characteristics of the material culture of indigenous people in the region $[13,17]$. Recognition for such non-monetary benefits, which 
include their socio-cultural significance and recreational contributions has increased over the past two decades [18]. Invariably, these non-material benefits are mainly exclusive to indigenous breeds since exotic and crossbreeds are culturally not acceptable as offerings to ancestors, spirit mediums and traditional healers [124]. For instance, Widi et al. [125] noted that some communities can maintain small populations of indigenous cattle (e.g., the Madura cattle of Indonesia), particular for certain cultural roles, and cannot be easily replaced by crossbreds. The authors further stated that the value of indigenous cattle used for certain cultural events can be 2 to 3.5 times greater than when the same animal is used for other functions. The value placed on an animal involved in cultural events further substantiates the importance of conserving these indigenous cattle breeds. Given the uncontrolled mating $[126,127]$ and/or preference by smallholder farmers for high-yielding exotic temperate breeds, it is important for government and private institutions to assist with re-introduction and maintenance of pure indigenous cattle breeds in the rural areas to avoid loss of this important genetic resource.

Within the rural community settings, indigenous cattle are a sign of wealth and living currencies $[17,37]$. They essentially contribute to cultural heritage and identity [18] and the overall enhancement of social capital among communities in the SADC region $[38,123]$. For instance, among pastoralists, they are central to one's self-esteem and are part of their identity [19]. This is the kind of wealth (intrinsic value) which cannot be equated to their financial worth but the symbolic value as wealth embedded in the animals [17,125]. In African traditional culture, ownership of such cattle is used as the pivot for evaluating one's wealth and hence infer social status $[36,37,123]$. Invariably, the larger the herd, the more respect and, appreciation are garnered within the local community and beyond. However, that respect is not exclusive to cattle wealth but to the level of livestock husbandry knowledge, skills and experience which the owner is anticipated to have $[17,128]$. The esteemed higher social status leads to better access to or authority over livelihood sources within the community [123].

Apart from cattle being important to socio-cultural values and identity of different ethnic groups in Southern Africa, some of its by-products are not included in defining its value or the roles to human livelihoods. For instance, besides using cow dung as manure and energy [31,129], rural people also use dung to improve aesthetic gratification and securing physical structures on homesteads. Cow dung is used to plaster floors and walls of traditional huts $[38,123]$, seal baskets and spread on the front yard where post-harvest processing (shelling/thrashing, winnowing, and drying of grain crops) is done. The wet dung is also mixed with water and sprinkled on plastered wall surfaces and floors prior to burnishing [130]. In a study by Chaminuka et al. [123] in the Tsonga culture, cow dung was mentioned by $86 \%$ of the respondents as an indirect benefit used for house decorations and floor polishing. Some rural communities donate products (i.e., meat, milk, manure and/or dung) or lend live animals to their neighbours [123]. These contributions are indirectly related to social capital which are the links and social relations, which local people utilise to pursue livelihood activities [123].

Other indigenous cattle by-products such as skins/hides and cattle tails (cow fly whiskers) are also highly valued within rural cultural systems. Cow skins are dried, slated and used for making traditional musical drums, Zulu warrior shields, clothing and seating mats that are used during traditional rituals and ceremonies. These products come from specific local cattle breeds that are closely linked with the cultural heritage and identity of a people. Ultimately, this bond features in the development of unique cultural landscapes that define the people and their histories and hence an improvement in their social capital within the region and beyond. Thus, due to the unique phenotypes of indigenous cattle, they are considered key components of the natural heritage, based on their contribution in shaping the heritage and recreational standards behind it $[18,129]$. Furthermore, their appearances in local landscapes remain an inspiration for arts, design and cultural activities [18,129].

The indigenous cattle play significant mediating and arbitrating roles for families and community social interrelationships [131,132]. Under traditional social governance systems (i.e., customary law), cattle in general and particularly pure indigenous breeds are used when pacifying the offended and disciplining the wrongdoer [17]. For example, within many tribes such as Shona and Nguni when a man or boy impregnates a woman or girl, he is asked to pay cattle as fine. This is done to discourage 
promiscuous relationships and restore dignity to the woman or girl [17]. Additionally, in rare cases where close relatives decide to marry each other, a ritual is conducted where a white indigenous cow is slaughtered. This is done to deliberately terminate the existing relationship between them before they get married. In many cultures within the SADC region, cattle are also used for settling traditional court fines and payment of crimes such as murder in cases where the deceased is believed to be avenging the murderer and his/her relatives. The use of cattle to settle disputes within various socio-cultural contexts elevates the welfare and identity of a people. It enforces the community to observe the rule of law which promotes stable societies where all people respect each other and have equal access to livelihoods.

During traditional marriage arrangements (i.e., dowry/bride price) among various traditional families across Southern Africa, cattle represent the cultural medium of payment [131]. Of much interest is a live cow, which is ritually paid to the bride's mother [17]. In addition, the father's herd has a stipulated number of live cattle that should be presented to the bridegroom's in-laws while, nowadays, the rest could be paid as cash. The dowry event is usually followed by wedding ceremonies where cows are slaughtered to feed the people $[17,58]$. In addition, the groom receives various gifts, including cattle from the father as seed to his own herd [17,58]. During these marriage negotiations, indigenous cattle are paid as a symbol of respect, appreciation and proving the capacity of the bridegroom to look after the bride and his new family $[17,58]$. Such practices approve the role of cattle in establishing social ties which allow people and communities to live together and share livelihoods in harmony. There is also a tradition that upon death of a man, his sons will inherit his cattle among other properties. If he does not have sons, the cattle can be inherited by his brothers and/or their sons. Inheritance and bequest related services are also linked to human gratification that comes with the understanding that local animals still exist and appreciation of the need to transfer knowledge, beliefs, traditions, and uses of such animals to future generations [128]. For instance, pastoralists have always developed and conveyed traditional livestock-related knowledge and information to their future generations [133]. These cultural practices provide a convenient framework which leads to a better understanding of local realities, intergenerational thinking as well as improved access and utilisation of rural-based livelihoods.

Religious beliefs and cultural practices involving ancestral communion rituals and appeasements, male circumcision, funerals and installation of spirit mediums, enthroning of traditional chiefs as well as exorcism of evil spirits at family, community and national level have remained part of the cultural activities of traditional people in Southern Africa [134]. To necessitate carrying out of these practices, besides live animals, cattle products such as meat, milk and blood are used by many communities $[112,135,136]$. Some traditional communities such as the Shona and Nguni keep a revered cattle bull which is believed to provide a spiritual currency for linking up with the ancestors [134]. The Maasai people ritually drink raw blood or a blood-milk mixture during cultural ceremonies or when sick [136]. These cultural activities are believed to pacify and/or bring back spirits of the ancestors for guidance, intercession and protection of families and communities [12]. Understanding beliefs and practices with regards to meat and its products is critical to the development of dietary recommendations, nutritional programs, and educational messages for the relevant communities [136]. For example, the pastoral Maasai diet solely consist purely of meat, milk and blood, which is highly symbolised and linked to their cultural beliefs. This will therefore promote strong cultural heritage where societies and families become united and work together in further developing sustainable rural livelihoods for the achievement of livelihoods, food and nutrition security in the SADC region.

\section{Contributions of Indigenous Cattle Breeds' Ecosystem Services to Livelihoods, Food Security and Nutrition Security}

Indigenous genetic cattle resources provide vital ecosystem services that contribute towards the livelihoods, food and nutrition security of rural people in their native countries [12,137]. Overall, cattle are often considered, a resource drain because they compete with humans for arable land and use of 
plants as feed versus food [129]. However, in Southern African smallholder farming systems, cattle rely primarily on rangelands, which are not suitable for cultivation of crops, and/or plant by-products not suitable for human consumption, thus reduce competition for land and food [138]. In addition, cattle transform foods that cannot be directly consumed by humans to high-biological-value foods [18]. This ability to convert less palatable and less nutrient dense to high-biological-value foods is often not factored into the net cost benefit of cattle production $[18,34]$. This justifies the importance of ascertaining the provision of ecosystem services of indigenous cattle genetic resources towards livelihoods, food and nutrition security of rural people.

Owing to their natural adaptation to the marginal environments, indigenous cattle breeds interact better with agroecosystems than their exotic counterparts [15]. For example, they naturally interact with ecosystems through grazing, browsing, fouling by urine and dung, trampling and pugging the soil [31]. Grazing and browsing fosters the removal of excess biomass and regrowth, fouling boost soil nutrient levels while trampling and pugging influence soil aeration and water cycling [18]. These physical actions promote the regeneration of agroecosystem and its provision of ecosystem services to local people $[31,38,129]$. The movement of cattle across landscapes and terrestrial ecosystem and time play a significant role in linking up habitats. Leroy et al. [129] states that ruminants connect habitats through dispersal of plant seeds which they carry in their digestive tracts, and insects attached to their skins and hoofs. For example, a study by Vignolio and Fernández [139] observed that cattle dung in Argentina was a vector of spreading seeds. Additionally, the passage of some seeds through the gut will lead to breaking of seed dormancy and hence germination of plants leading to the rebirth of ecosystems [31,129]. Furthermore, cattle grazing and movement promote the creation and maintenance of fire breaks which reduces the spread of rangeland fires in the region [140]. They have the potential to control unwanted plants and in the management of biomass residues which minimises the spread of weeds and invasive plants [18]. However, the problem occurs when there is mismanagement of the rangelands (e.g., high stocking rates and continuous grazing), which is often the case in smallholder farming areas [141]. If this occurs, there are possibilities to alter biological communities and ecosystem functions, for example, it can lead to soil compaction and/or, reduced plant growth, and high levels of erosion $[142,143]$. The ecosystem services of indigenous cattle or the detriment thereof, and are dependent on the grazing management systems.

These are some of the non-material cultural ecosystem services/benefits that enhance people's cultural and spiritual needs, including aesthetic and recreational gratification [128]. For example, some traditions surrounding cattle keeping have been known to promote rural tourism within the SADC region. Overall, grazing indigenous cattle contribute to a magnificently pleasant rural landscape. The scenic beauty of rural landscape provide spiritual and inspirational experiences to the local people and tourists [144]. For example, the Maasai pastoralists in northern Tanzania have a local community-based cultural tourism programme, which gives tourists the opportunity to herd Ankole cattle and perform other livestock-related activities on the shores of Lake Natron [31]. Therefore, despite some of these activities yielding better economic returns, such practices remain significant for human socio-cultural well-being, assist in maintaining stable social ecosystems and widen rural livelihood sources. Therefore, sustainable use of ecosystems due to interactions by indigenous cattle resources could directly and indirectly contribute to food and nutrition security through the provisioning of ecosystem services that facilitate food production, build income-generating prospects as well as providing energy for cooking.

\section{Conclusions}

The genetic resource of indigenous cattle play multiple and diverse roles critical for addressing livelihood, food and nutrition insecurity in the SADC region. They directly contribute to food and nutrition security through provision of food (i.e., beef, blood and milk) that is rich in energy, amino acids, protein, minerals, vitamins and fatty acids essential for human health and development. The indirect contributions of indigenous cattle to food and nutrition security are through sales of live animals, products and/or by-products for cash income to purchase staple foods, farm inputs, and 
provision and sales of manure, transport and draught power. Indigenous cattle can enhance sustainable livelihoods by providing cash income to pay for food and other essentials for the household. The other contributions of indigenous cattle to sustainable livelihood include socio-cultural ones (e.g., bride price, self-esteem, ceremonies, ancestral sacrifices, indigenous knowledge systems, cultural heritage, identity and bequest) and ecosystem services (e.g., biorecycling, weed control and moderation of rangeland fires). It is important to note that cultural and indigenous knowledge systems contributions to sustainable livelihoods are exclusive to indigenous cattle and cannot be substituted by exotic breeds. Indigenous cattle breeds also provide genetic diversity for insurance against current and future challenges (i.e., diseases, parasites, changes in climate and market demands). The genetic diversity and knowledge systems associated with indigenous cattle are, however, declining mainly as a result of replacement, unstructured crossbreeding and focus on specialised production systems which put emphasis on a single productive trait. To prevent the possible extinction of indigenous cattle breeds and ensure their optimal livelihoods, food and nutrition security in future, it is important to develop a regional strategic plan to promote sustainable use indigenous cattle genetic resources.

Author Contributions: Conceptualisation, C.M.; O.M. and O.C.C. wrote the original draft; O.M. and O.C.C. made equal contributions to the manuscript. Editorial inputs, C.M., G.M. and K.D. All authors have read and agreed to the published version of the manuscript.

Funding: South African Research Chairs Initiative (SARChI) partly funded by the South African Department of Science and Technology (DST) (UID number: 84633), as administered by the National Research Foundation (NRF) of South Africa for providing funds for the research.

Acknowledgments: O.C.C. acknowledges Consolidoc Fellowship from the SARChI partly funded by the South African DST (UID number: 84633), as administered by the NRF of South Africa.

Conflicts of Interest: The authors declare no conflict of interest.

\section{References}

1. SADC-RVAA. Synthesis Report on the State of Food and Nutrition Security and Vulnerability in Southern Africa; SADC-RVAA: Windhoek, Namibia, 2019.

2. FAO; IFAD; UNICEF; WFP; WHO. The State of Food Security and Nutrition in the World 2019. Safeguarding Against Economic Slowdowns and Downturns; Food and Agriculture Organization of the United Nations: Rome, Italy, 2019; ISBN 978-92-5-109888-2.

3. SADC-RVAA. SADC Regional Vulnerability Assessment and Analysis Synthesis Report; SADC-RVAA: Windhoek, Namibia, 2017.

4. El Bilali, H. Research on agro-food sustainability transitions: Where are food security and nutrition? Food Secur. 2019, 11, 559-577. [CrossRef]

5. Bohle, H.-G. Sustainable livelihood security. Evolution and application. In Facing Global Environmental Change: Environmental, Human, Energy, Food, Health and Water Security; Brauch, H.G., Kameri-Bonte, P., Spring, U.O., Behera, N.C., Grin, J., Chourou, B., Mesjasz, C., Krummenacher, H., Eds.; Springer International Publishing: Berlin, Germany, 2009; pp. 521-528. ISBN 978-3-540-68487-9.

6. FAO. Coming to Terms with Terminology: Food Security Nutrition Security Food Security and Nutrition Food and Nutrition Security; FAO: Rome, Italy, 2012; Volume CFS 2012/3.

7. FAO. Evaluation of FAO's Role and Work in Nutrition; FAO: Rome, Italy, 2011.

8. Frankenberger, T.R.; McCaston, M.K. The household livelihood security concept. Security 1998, 30-35.

9. Chambers, R. Editorial introduction: Vulnerability, coping and policy. IDS Bull. 1989, 20, 1-7. [CrossRef]

10. FAO. The State of the World's Animal Genetic Resources for Food and Agriculture; Rischkowsky, B., Pilling, D., Eds.; Commission on Genetic Resources for Food and Agriculture, Food and Agriculture Organization of the United Nations: Rome, Italy, 2007; ISBN 9789251057629.

11. Chingala, G.; Raffrenato, E.; Dzama, K.; Hoffman, L.C.; Mapiye, C. Towards a regional beef carcass classification system for Southern Africa beef production and marketing systems in Southern Africa. S. Afr. J. Anim. Sci. 2017, 47, 408-423. [CrossRef] 
12. Nyamushamba, G.B.; Mapiye, C.; Tada, O.; Halimani, T.E.; Muchenje, V. Conservation of indigenous cattle genetic resources in Southern Africa's smallholder areas: Turning threats into opportunities-A review. Asian Australas. J. Anim. Sci. 2017, 30, 603-621. [CrossRef] [PubMed]

13. Mwai, O.; Hanotte, O.; Kwon, Y.J.; Cho, S. African indigenous cattle: Unique genetic resources in a rapidly changing world. Asian Australas. J. Anim. Sci. 2015, 28, 911-921. [CrossRef] [PubMed]

14. FAO/IAEA. Genetic Characterization of Indigenous Cattle Breeds in Zambia - Which Way Forward? Available online: http://www-naweb.iaea.org/nafa/news/2011-zambia-cattle-breeds.html (accessed on 17 January 2019).

15. AU-IBAR. The State of Farm Animal Genetic Resources; Nouala, S., Bosso, N.A., Mbole-Kariuki, M., Nengomasha, E., Tchangai, P., Eds.; AU-IBAR: Nairobi, Kenya, 2019; ISBN 978-9966-63-198-5.

16. van Marle-Köster, E.; Visser, C. Genetic improvement in South African livestock: Can genomics bridge the gap between the developed and developing sectors? Front. Genet. 2018, 9, 331. [CrossRef]

17. Shava, S.; Masuku, S. Living currency: The multiple roles of livestock in livelihood sustenance and exchange in the context of rural indigenous communities in southern Africa. S. Afr. J. Environ. Educ. 2019, 35. [CrossRef]

18. Hoffmann, I.; From, T.; Boerma, D. Ecosystem Services Provided by Livestock Species and Breeds, with Special Consideration to the Contributions of Small-Scale Livestock Keepers and Pastoralists; Background Study Paper No. 66; Commission on Genetic Resources for Food and Agriculture: Rome, Italy, 2014.

19. Tamou, C.; de Boer, I.J.M.; Ripoll-Bosch, R.; Oosting, S.J. Understanding roles and functions of cattle breeds for pastoralists in Benin. Livest. Sci. 2018, 210, 129-136. [CrossRef]

20. Frankham, R. Stress and adaptation in conservation genetics. J. Evol. Biol. 2005, 18, 750-755. [CrossRef]

21. Ndlovu, T.; Chimonyo, M.; Muchenje, V. Monthly changes in body condition scores and internal parasite prevalence in Nguni, Bonsmara and Angus steers raised on sweetveld. Trop. Anim. Health Prod. 2009, 41, 1169-1177. [CrossRef] [PubMed]

22. Spickett, A.M.; De Klerk, D.; Enslin, C.B.; Scholtz, M.M. Resistance of Nguni, Bonsmara and Hereford cattle to ticks in a Bushveld region of South Africa. Onderstepoort J. Vet. Res. 1989, 56, 245-250. [PubMed]

23. Muchenje, V.; Dzama, K.; Chimonyo, M.; Raats, J.G.; Strydom, P.E. Tick susceptibility and its effects on growth performance and carcass characteristics of Nguni, Bonsmara and Angus steers raised on natural pasture. Animal 2008, 2, 298-304. [CrossRef] [PubMed]

24. Marufu, M.C.; Chimonyo, M.; Mapiye, C.; Dzama, K. Tick loads in cattle raised on sweet and sour rangelands in the low-input farming areas of South Africa. Trop. Anim. Health Prod. 2011, 43, 307-313. [CrossRef]

25. Marufu, M.C.; Chimonyo, M.; Dzama, K.; Mapiye, C. Seroprevalence of tick-borne diseases in communal cattle reared on sweet and sour rangelands in a semi-arid area of South Africa. Vet. J. 2010, 184, 71-76. [CrossRef]

26. Osler, E.; Linington, M.; Ford, Y.; Swart, D. Grazing behaviour and forage utilization of Nguni, Afrikaner and Simmentaler cattle. Ann. Zootech. 1995, 44, 322. [CrossRef]

27. Ndlovu, T.; Chimonyo, M.; Okoh, A.I.; Muchenje, V.; Dzama, K.; Dube, S.; Raats, J.G. A comparison of nutritionally-related blood metabolites among Nguni, Bonsmara and Angus steers raised on sweetveld. Vet. J. 2009, 179, 273-281. [CrossRef]

28. Mapiye, C.; Chimonyo, M.; Dzama, K.; Marufu, M.C. Protein status of indigenous Nguni and crossbred cattle in the semi-arid communal rangelands in South Africa. Asian Australas. J. Anim. Sci. 2010, 23, 213-225. [CrossRef]

29. Scholtz, M.M.; Theunissen, A. The use of indigenous cattle in terminal cross-breeding to improve beef cattle production in Sub-Saharan Africa. Anim. Genet. Resour. 2010, 46, 33-39. [CrossRef]

30. Mokolobate, M.C.; Theunissen, A.; Scholtz, M.M.; Neser, F.W.C. Sustainable crossbreeding systems of beef cattle in the era of climate change. S. Afr. J. Anim. Sci. 2014, 44, S8-S11.

31. FAO. The Second Report on the State of the World's Animal Genetic Resources for Food and Agriculture; Scherf, B.D., Pilling, D., Eds.; FAO Commission on Genetic Resources for Food and Agriculture Assessments: Rome, Italy, 2015; ISBN 9789251088203.

32. Mapiye, C.; Chikwanha, O.C.; Chimonyo, M.; Dzama, K. Strategies for sustainable use of indigenous cattle genetic resources in Southern Africa. Diversity 2019, 11, 214. [CrossRef] 
33. Frelat, R.; Lopez-Ridaura, S.; Giller, K.E.; Herrero, M.; Douxchamps, S.; Djurfeldt, A.A.; Erenstein, O.; Henderson, B.; Kassie, M.; Paul, B.K.; et al. Drivers of household food availability in sub-Saharan Africa based on big data from small farms. Proc. Natl. Acad. Sci. USA 2016, 113, 458-463. [CrossRef] [PubMed]

34. Smith, J.; Sones, K.; Grace, D.; MacMillan, S.; Tarawali, S.; Herrero, M. Beyond milk, meat, and eggs: Role of livestock in food and nutrition security. Anim. Front. 2013, 3, 6-13. [CrossRef]

35. Enahoro, D.; Lannerstad, M.; Pfeifer, C.; Dominguez-Salas, P. Contributions of livestock-derived foods to nutrient supply under changing demand in low- and middle-income countries. Glob. Food Sec. 2018, 19, 1-10. [CrossRef]

36. Barrett, J.C. The economic role of cattle in communal farming systems in Zimbabwe. In Proceedings of the Socio-economic Impact of Improved Tick and Tick-borne Disease Control in Zimbabwe, Harare, Zimbabwe, 9 May 1991.

37. Scoones, I. The economic value of livestock in the communal areas of southern Zimbabwe. Agric. Syst. 1992, 39, 339-359. [CrossRef]

38. Randolph, T.F.; Schelling, E.; Grace, D.; Nicholson, C.F.; Leroy, J.L.; Cole, D.C.; Demment, M.W.; Omore, A.; Zinsstag, J.; Ruel, M. Role of livestock in human nutrition and health for poverty reduction in developing countries. J. Anim. Sci. 2007, 85, 2788-2800. [CrossRef] [PubMed]

39. Swanepol, F.; Stroebel, A.; Moyo, S. The Role of Livestock in Developing Communities: Enhancing Multifunctionality; Swanepol, F., Stroebel, A., Moyo, S., Eds.; UFS: Bloemfontein, South Africa; CTA: Wageningen, The Netherlands, 2010; ISBN 978-0-86886-798-4.

40. Steinfeld, H.; Mack, S. Livestock Development Strategies. 1997. Available online: http://www.fao.org/3/ V8180T/v8180T0a.htm (accessed on 25 November 2019).

41. Pighin, D.; Pazos, A.; Chamorro, V.; Paschetta, F.; Cunzolo, S.; Godoy, F.; Messina, V.; Pordomingo, A.; Grigioni, G. A contribution of beef to human health: A review of the role of the animal production systems. Sci. World J. 2016, 2016, 8681491. [CrossRef]

42. Leroy, F.; Cofnas, N. Should dietary guidelines recommend low red meat intake? Crit. Rev. Food Sci. Nutr. 2019. [CrossRef]

43. Zeraatkar, D.; Johnston, B.C.; Bartoszko, J.; Cheung, K.; Bala, M.M.; Valli, C.; Rabassa, M.; Sit, D.; Milio, K.; Sadeghirad, B.; et al. Effect of lower versus higher red meat intake on cardiometabolic and cancer outcomes. Ann. Intern. Med. 2019, 171, 721-731. [CrossRef]

44. Warris, P.D. Meat Science: An Introductory Text, 2nd ed.; Warris, P.D., Ed.; CABI Publishing: Wallingford, UK, 2010; ISBN 9781845931.

45. Williams, P. Nutritional composition of red meat. Nutr. Diet. 2007, 64, S113-S119. [CrossRef]

46. Shabtay, A. Adaptive traits of indigenous cattle breeds: The Mediterranean Baladi as a case study. Meat Sci. 2015, 109, 27-39. [CrossRef] [PubMed]

47. Thompson, J.; Polkinghorne, R.; Gee, A.; Motiang, D.; Strydom, P.; Mashau, M.; Ng'ambi, J.; DeKock, R.; Heather, B. Beef Palatability in the Republic of South Africa: Implications for Niche-Marketing Strategies; Australian Centre for International Agricultural Research: Canberra, ACT, Australia, 2010.

48. Ransom, E. Botswana's beef global commodity chain: Explaining the resistance to change. J. Rural Stud. 2011, 27, 431-439. [CrossRef]

49. Strydom, P.E.; Naude, R.T.; Smith, M.F.; Scholtz, M.M.; Van Wyk, J.B. Characterisation of indigenous African cattle breeds in relation to meat quality traits. Meat Sci. 2000, 55, 79-88. [CrossRef]

50. Strydom, P.E.; Naudé, R.T.; Smith, M.F.; Scholtz, M.M.; Van Wyk, J.B. Characterization of indigenous African cattle breeds in relation to carcass characteristics. Anim. Sci. 2000, 70, 241-252. [CrossRef]

51. Mapiye, C.; Chimonyo, M.; Dzama, K.; Strydom, P.E.; Muchenje, V.; Marufu, M.C. Nutritional status, growth performance and carcass characteristics of Nguni steers supplemented with Acacia karroo leaf-meal. Livest. Sci. 2009, 126, 206-214. [CrossRef]

52. Mapiye, C.; Chimonyo, M.; Dzama, K.; Muchenje, V.; Strydom, P.E. Meat quality of Nguni steers supplemented with Acacia karroo leaf-meal. Meat Sci. 2010, 84, 621-627. [CrossRef]

53. Mapiye, C.; Chimonyo, M.; Dzama, K.; Hugo, A.; Strydom, P.E.; Muchenje, V. Fatty acid composition of beef from Nguni steers supplemented with Acacia karroo leaf-meal. J. Food Compos. Anal. 2011, 24, 523-528. [CrossRef] 
54. Muchenje, V.; Hugo, A.; Dzama, K.; Chimonyo, M.; Strydom, P.E.; Raats, J.G. Cholesterol levels and fatty acid profiles of beef from three cattle breeds raised on natural pasture. J. Food Compos. Anal. 2009, 22, 354-358. [CrossRef]

55. Chingala, G.; Raffrenato, E.; Dzama, K.; Hoffman, L.C.; Mapiye, C. Carcass and meat quality attributes of Malawi Zebu steers fed Vachellia polyacantha leaves or Adansonia digitata seed as alternative protein sources to Glycine max. S. Afr. J. Anim. Sci. 2019, 49, 396-402. [CrossRef]

56. Muchenje, V.; Dzama, K.; Chimonyo, M.; Raats, J.G.; Strydom, P.E. Meat quality of Nguni, Bonsmara and Aberdeen Angus steers raised on natural pasture in the Eastern Cape, South Africa. Meat Sci. 2008, 79, 20-28. [CrossRef]

57. Zhang, Z.; Goldsmith, P.D.; Winter-Nelson, A. The importance of animal source foods for nutrient sufficiency in the developing world: The Zambia scenario. Food Nutr. Bull. 2016, 37, 303-316. [CrossRef] [PubMed]

58. Musemwa, L.; Mushunje, A.; Chimonyo, M.; Mapiye, C. Low cattle market off-take rates in communal production systems of South Africa: Causes and mitigation strategies. J. Sustain. Dev. Afr. 2010, 12, $209-226$.

59. Mapiye, C.; Chimonyo, M.; Dzama, K.; Raats, J.G.; Mapekula, M. Opportunities for improving Nguni cattle production in the smallholder farming systems of South Africa. Livest. Sci. 2009, 124, 196-204. [CrossRef]

60. Waters-Bayer, A.; Bayer, W. The role of livestock in the rural economy. Nomad. People. 1992, 31, 3-18.

61. Sitali, D.C.; Mumba, C.; Skjerve, E.; Mweemba, O.; Kabonesa, C.; Mwinyi, M.O.; Nyakarahuka, L.; Muma, J.B. Awareness and attitudes towards anthrax and meat consumption practices among affected communities in Zambia: A mixed methods approach. PLoS Negl. Trop. Dis. 2017, 11, e0005580. [CrossRef] [PubMed]

62. Shackleton, C.M.; Shackleton, S.E.; Netshiluvhi, T.R.; Mathabela, F.R. The contribution and direct-use value of livestock to rural livelihoods in the Sand River catchment, South Africa. Afr. J. Range Forage Sci. 2005, 22, 127-140. [CrossRef]

63. Willett, W.; Rockström, J.; Loken, B.; Springmann, M.; Lang, T.; Vermeulen, S.; Garnett, T.; Tilman, D.; DeClerck, F.; Wood, A.; et al. Food in the Anthropocene: The EAT-Lancet Commission on healthy diets from sustainable food systems. Lancet 2019, 393, 447-492. [CrossRef]

64. Mottet, A.; Teillard, F.; Boettcher, P.; De’Besi, G.; Besbes, B. Review: Domestic herbivores and food security: Current contribution, trends and challenges for a sustainable development. Animal 2018, 12, S188-S198. [CrossRef]

65. Van Hal, O.; de Boer, I.J.M.; Muller, A.; de Vries, S.; Erb, K.H.; Schader, C.; Gerrits, W.J.J.; van Zanten, H.H.E. Upcycling food leftovers and grass resources through livestock: Impact of livestock system and productivity. J. Clean. Prod. 2019, 219, 485-496. [CrossRef]

66. Mapekula, M.; Chimonyo, M.; Mapiye, C.; Dzama, K. Fatty acid, amino acid and mineral composition of milk from Nguni and local crossbred cows in South Africa. J. Food Compos. Anal. 2011, 24, 529-536. [CrossRef]

67. Myburgh, J.; Osthoff, G.; Hugo, A.; de Wit, M.; Nel, K.; Fourie, D. Comparison of the milk composition of free-ranging indigenous African cattle breeds. S. Afr. J. Anim. Sci. 2012, 42, 1-14. [CrossRef]

68. Banda, L.J.; Kamwanja, L.A.; Chagunda, M.G.G.; Ashworth, C.J.; Roberts, D.J. Status of dairy cow management and fertility in smallholder farms in Malawi. Trop. Anim. Health Prod. 2012, 44, 715-727. [CrossRef] [PubMed]

69. Chagunda, M.G.G.; Mwangwela, A.; Mumba, C.; Dos Anjos, F.; Kawonga, B.S.; Hopkins, R.; Chiwona-Kartun, L. Assessing and managing intensification in smallholder dairy systems for food and nutrition security in Sub-Saharan Africa. Reg. Environ. Chang. 2016, 16, 2257-2267. [CrossRef]

70. Choudhury, S.; Headey, D.D. Household dairy production and child growth: Evidence from Bangladesh. Econ. Hum. Biol. 2018, 30, 150-161. [CrossRef]

71. Hoddinott, J.; Headey, D.; Dereje, M. Cows, missing milk markets, and nutrition in rural Ethiopia. J. Dev. Stud. 2015, 51, 958-975. [CrossRef]

72. Rawlins, R.; Pimkina, S.; Barrett, C.B.; Pedersen, S.; Wydick, B. Got milk? The impact of Heifer International's livestock donation programs in Rwanda on nutritional outcomes. Food Policy 2014, 44, 202-213. [CrossRef]

73. Mapekula, M.; Chimonyo, M.; Mapiye, C.; Dzama, K. Milk production and calf rearing practices in the smallholder areas in the Eastern Cape Province of South Africa. Trop. Anim. Health Prod. 2009, 41, 1475-1485. [CrossRef]

74. Masama, E.; Kusina, N.T.; Sibanda, S.; Majoni, C. Reproduction and lactational performance of cattle in a smallholder dairy system in Zimbabwe. Trop. Anim. Health Prod. 2003, 35, 117-129. [CrossRef]

75. Mapiye, C.; Chimonyo, M.; Muchenje, V.; Dzama, K.; Marufu, M.C.; Raats, J.G. Potential for value-addition of Nguni cattle products in the communal areas of South Africa: A review. Afr. J. Agric. Res. 2007, 2, 488-495. 
76. Muchenje, V.; Sikhosana, J.L.N.; Assan, N. Milk yield of Jersey $\times$ Nguni and Jersey $\times$ Tuli F1 and F2 cows reared under smallholder farming conditions. S. Afr. J. Anim. Sci. 2007, 8, 7-10.

77. Ngongoni, N.T.; Mapiye, C.; Mwale, M.; Mupeta, B. Effect of supplementing a high-protein ram press sunflower cake concentrate on smallholder milk production in Zimbabwe. Trop. Anim. Health Prod. 2007, 39, 297-307. [CrossRef] [PubMed]

78. Grobler, S.M.; Scholtz, M.M.; Bester, J.; Mamabolo, J.M.; Ramsay, K.A. Dairy production systems in the emerging and communal sectors of South Africa: Results from a structured survey. Appl. Anim. Husb. Rural Dev. 2008, 1, 25-30.

79. Maiwashe, A.; Nengovhela, N.B.; Nephawe, K.A.; Sebei, J.; Netshilema, T.; Mashaba, H.D.; Nesengani, L.; Norris, D. Estimates of lactation curve parameters for Bonsmara and Nguni cattle using the weigh-suckle-weigh technique. S. Afr. J. Anim. Sci. 2013, 43, S12-S16. [CrossRef]

80. Chimonyo, M.; Kusina, N.; Hamudikuwanda, H.; Nyoni, O.; Ncube, I. Effects of dietary supplementation and work stress on ovarian activity in non-lactating Mashona cows in a small-holder farming area of Zimbabwe. Anim. Sci. 2000, 70, 317-323. [CrossRef]

81. Schoeman, S.J. Recent research into the production potential of indigenous cattle with special reference to the Sanga. S. Afr. J. Anim. Sci. 1989, 19, 55-61.

82. Yadav, A.; Gupta, R.; Garg, V.K. Organic manure production from cow dung and biogas plant slurry by vermicomposting under field conditions. Int. J. Recycl. Org. Waste Agric. 2013, 2, 21. [CrossRef]

83. Sager, M. Trace and nutrient elements in manure, dung and compost samples in Austria. Soil Biol. Biochem. 2007, 39, 1383-1390. [CrossRef]

84. Randela, R. An economic assessment of the value of cattle to the rural communities in the former Venda region. Dev. S. Afr. 2003, 20, 89-103. [CrossRef]

85. Peltre, C.; Nyord, T.; Bruun, S.; Jensen, L.S.; Magid, J. Repeated soil application of organic waste amendments reduces draught force and fuel consumption for soil tillage. Agric. Ecosyst. Environ. 2015, 211, 94-101. [CrossRef]

86. Whalen, J.K.; Chang, C.; Clayton, G.W. Cattle manure and lime amendments to improve crop production of acidic soils in northern Alberta. Can. J. Soil Sci. 2002, 82, 227-238. [CrossRef]

87. Whalen, J.K.; Chang, C.; Olson, B.M. Nitrogen and phosphorus mineralization potentials of soils receiving repeated annual cattle manure applications. Biol. Fertil. Soils 2001, 34, 334-341. [CrossRef]

88. Font-Palma, C. Methods for the treatment of cattle manure-A review. J. Carbon Res. 2019, 5, 27. [CrossRef]

89. Naramabuye, F.X.; Haynes, R.J.; Modi, A.T. Cattle manure and grass residues as liming materials in a semi-subsistence farming system. Agric. Ecosyst. Environ. 2008, 124, 136-141. [CrossRef]

90. Food and Agriculture Organization of the United Nations. Nitrogen Inputs to Agricultural Soils from Livestock Manure. New Statistics; FAO: Rome, Italy, 2018; Volume 24, ISBN 9789251300244.

91. Simalenga, T.E.; Belete, A.; Mseleni, N.A.; Jongisa, L.L. Assessing the profitability of using animal traction under smallholder farming conditions. S. Afr. J. Agric. Ext. 2000, 29, 1-9.

92. Eghball, B. Liming effects of beef cattle feedlot manure or compost. Commun. Soil Sci. Plant Anal. 1999, 30, 2563-2570. [CrossRef]

93. Whalen, J.K.; Chang, C.; Clayton, G.W.; Carefoot, J.P. Cattle manure amendments can increase the pH of acid soils. Soil Sci. Soc. Am. J. 2000, 64, 962-966. [CrossRef]

94. Tucho, G.T.; Nonhebel, S. Bio-wastes as an alternative household cooking energy source in Ethiopia. Energies 2015, 8, 9565-9583. [CrossRef]

95. Nape, K.M.; Magama, P.; Moeletsi, M.E.; Tongwane, M.I.; Nakana, P.M.; Mliswa, V.K.; Motsepe, M.; Madikiza, S. Introduction of household biogas digesters in rural farming households of the Maluti-a-Phofung municipality, South Africa. J. Energy S. Afr. 2019, 30, 28-37. [CrossRef]

96. Msibi, S.S.; Kornelius, G. Potential for domestic biogas as household energy supply in South Africa. J. Energy S. Afr. 2017, 28, 1-13. [CrossRef]

97. Pearson, R.A. Resource requirements for draught animal power. Br. Soc. Anim. Prod. Occas. Publ. 1993, 16, 57-67. [CrossRef]

98. Chanie, M.; Fentahun, T.; Mitiku, T.; Berhan, M. Strategies for improvement of draft animal power supply for cultivation in Ethiopia: A review. Eur. J. Biol. Sci. 2012, 4, 96-104. 
99. Okello, W.O.; Muhanguzi, D.; MacLeod, E.T.; Welburn, S.C.; Waiswa, C.; Shaw, A.P. Contribution of draft cattle to rural livelihoods in a district of southeastern Uganda endemic for bovine parasitic diseases: An economic evaluation. Parasites Vectors 2015, 8, 571. [CrossRef] [PubMed]

100. Guthiga, P.M.; Karugia, J.T.; Nyikal, R.A. Does use of draft animal power increase economic efficiency of smallholder farms in Kenya? Renew. Agric. Food Syst. 2007, 22, 290-296. [CrossRef]

101. Tawonezvi, P.; Makuza, S.; Moyo, S.; Nengomasha, E. Zimbabwe Country Report on the State of the World's Animal Genetic Resources; Agricultural Research Council: Harare, Zimbabwe, 2004.

102. FAO. Draught Animal Power: An Overview; FAO: Rome, Italy, 2010.

103. Ellis-Jones, J.; Neill, D. The contribution of draught animal power to sustainable livelihoods in sub-Saharan Africa: An example from Zimbabwe. In Proceedings of the Animal Traction, Health and Technology, the Role of Draught and Pack Animals in the 21st Century, London, UK, 28 October 2000; pp. 1-8.

104. Lawrence, P.R.; Pearson, R.A. Use of draught animal power on small mixed farms in Asia. Agric. Syst. 2002, 71, 99-110. [CrossRef]

105. FAO. Invisible Guardians_Women Manage Livestock Diversity; FAO: Rome, Italy, 2012; Available online: http: //www.fao.org/fileadmin/user_upload/ags/publications/draugth_ap_overview.pdf (accessed on 28 October 2019).

106. Salmon, G.; Teufel, N.; Baltenweck, I.; van Wijk, M.; Claessens, L.; Marshall, K. Trade-offs in livestock development at farm level: Different actors with different objectives. Glob. Food Sec. 2018, 17, 103-112. [CrossRef]

107. Galiè, A.; Teufel, N.; Girard, A.W.; Baltenweck, I.; Dominguez-Salas, P.; Price, M.J.; Jones, R.; Lukuyu, B.; Korir, L.; Raskind, I.G.; et al. Women's empowerment, food security and nutrition of pastoral communities in Tanzania. Glob. Food Sec. 2019, 23, 125-134. [CrossRef]

108. Verhart, N.; van den Wijngaart, A.; Dhamankar, M.; Danielsen, K. Bringing Agriculture and Nutrition Together; Royal Tropical Institute (KIT) and Netherlands Development Organisation (SNV): Amsterdam, The Netherlands, 2015.

109. Alao, B.O.; Falowo, A.B.; Chulayo, A.; Muchenje, V. The potential of animal by-products in food systems: Production, prospects and challenges. Sustainability 2017, 9, 1089. [CrossRef]

110. Oiye, S.; Simel, J.O.; Oniang'o, R.; Johns, T. The Maasai food system and food and nutrition security. In Indigenous Peoples' Food Systems: The Many Dimensions of Culture, Diversity and Environment for Nutrition and Health; FAO: Rome, Italy, 2009; pp. 231-249. ISBN 9789251060711.

111. Wurzinger, M.; Ndumu, D.; Baumung, R.; Drucker, A.; Okeyo, A.M.; Semambo, D.K.; Byamungu, N.; Sölkner, J. Comparison of production systems and selection criteria of Ankole cattle by breeders in Burundi, Rwanda, Tanzania and Uganda. Trop. Anim. Health Prod. 2006, 38, 571-581. [CrossRef]

112. Fayemi, P.O.; Muchenje, V. Meat in African context: From history to science. Afr. J. Biotechnol. 2012, 11, 1298-1306. [CrossRef]

113. Gebremedhin, B.; Ehui, S. Essential Actions to Meet Quality Requirements of Hides, Skins and Semi-Processed Leather from Africa; Common Fund for Commodities: Amsterdam, Netherlands, 2002.

114. Mahmud, A. Development Potential and Constraints of Hides and Skins Marketing in Ethiopia; LMA: Addis Ababa, Ethiopia, 1999.

115. Soji, Z.; Chikwanda, D.; Chikwanda, A.T.; Jaja, I.F.; Mushonga, B.; Muchenje, V. Relevance of the formal red meat classification system to the South African informal livestock sector. S. Afr. J. Anim. Sci. 2015, 45, 263-277.

116. Gwiriri, L.C.; Bennett, J.; Mapiye, C.; Marandure, T.; Burbi, S. Constraints to the sustainability of a 'systematised' approach to livestock marketing amongst smallholder cattle producers in South Africa. Int. J. Agric. Sustain. 2019, 17, 189-204. [CrossRef]

117. Rootman, G.T.; Stevens, J.B.; Mollel, N.M. Policy opportunities to enhance the role of smallholder livestock systems in Limpopo Province of South Africa. S. Afr. J. Agric. Ext. 2015, 43, 91-104. [CrossRef]

118. Mapekula, M.; Chimonyo, M.; Mapiye, C.; Dzama, K. Milk utilisation patterns in the low-input production systems in South Africa. Trop. Anim. Health Prod. 2010, 42, 1413-1419. [CrossRef] [PubMed]

119. Nabarro, D.; Wannous, C. The potential contribution of livestock to food and nutrition security: The application of the One Health approach in livestock policy and practice. Rev. Sci. Tech. 2014, 33, 475-485. [CrossRef] 
120. McRoberts, K.C.; Nicholson, C.F.; Parsons, D.; Van Nam, L.; Ba, N.X.; Ketterings, Q.M.; Cherney, D.J.R. Structure and impact of cattle manure trade in crop-livestock systems of Vietnam. Renew. Agric. Food Syst. 2018, 33, 86-101. [CrossRef]

121. Gwanya, T.T. South Africa Position Paper on Rural Development-A Model for the Comprehensive Rural Develpment Programme; Government of South Africa: Pretoria, South Africa, 2010.

122. Livestock Data Innovation in Africa. Business and Livelihoods in African Livestock: Investments to Overcome Information Gaps; FAO: Rome, Italy, 2014.

123. Chaminuka, P.; Udo, H.M.J.; Eilers, K.C.H.A.M.; van der Zijpp, A. Livelihood roles of cattle and prospects for alternative land uses at the wildlife/livestock interface in South Africa. Land Use Policy 2014, 38, 80-90. [CrossRef]

124. Bere-Chikara, F. Cattle: The life blood of Shona society. In Shona Customs: Essays by African Writers; Kileff, C., Kileff, P., Eds.; Mambo Press: Harare, Zimbabwe, 1970; pp. 20-23.

125. Widi, T.S.M.; Udo, H.M.J.; Oldenbroek, K.; Budisatria, I.G.S.; Baliarti, E.; van der Zijpp, A.J. Unique cultural values of Madura cattle: Is cross-breeding a threat? Anim. Genet. Resour. 2014, 54, 141-152. [CrossRef]

126. Scholtz, M.M.; Bester, J.; Mamabolo, J.M.; Ramsay, K.A. Results of the national beef cattle survey undertaken in South Africa. Appl. Anim. Husb. Rural Dev. 2008, 1, 1-9.

127. Rege, J.E.O.; Marshall, K.; Notenbaert, A.; Ojango, J.M.K.; Okeyo, A.M. Pro-poor animal improvement and breeding-What can science do? Livest. Sci. 2011, 136, 15-28. [CrossRef]

128. Ovaska, U.; Soini, K. Native breeds as providers of ecosystem services: The stakeholders' perspective. TRACE Finn. J. Hum. Animal Stud. 2016, 2, 29-51.

129. Leroy, G.; Baumung, R.; Boettcher, P.; Besbes, B.; From, T.; Hoffmann, I. Animal genetic resources diversity and ecosystem services. Glob. Food Sec. 2018, 17, 84-91. [CrossRef]

130. Srivastava, M.; Kumar, V. The methods of using low cost housing techniques in India. J. Build. Eng. 2018, 15, 102-108. [CrossRef]

131. Bettencourt, E.M.V.; Tilman, M.; Narciso, V.; da Silva Carvalho, M.L.; de Sousa Henriques, P.D. The livestock roles in the wellbeing of rural communities of Timor-Leste. Rev. Econ. Sociol. Rural. 2015, 53, S063-S080. [CrossRef]

132. Marsoner, T.; Vigl, L.; Manck, F.; Jaritz, G.; Tappeiner, U.; Tasser, E. Indigenous livestock breeds as indicators for cultural ecosystem services: A spatial analysis within the Alpine Space. Ecol. Indic. 2018, 94, 55-63. [CrossRef]

133. Gómez-Baggethun, E.; Muradian, R. In markets we trust? Setting the boundaries of market-based instruments in ecosystem services governance. Ecol. Econ. 2015, 117, 217-224. [CrossRef]

134. Mhlanga, F.N.; Khombe, C.T.; Makuza, S.M. Indigenous Livestock Genotypes of Zimbabwe; University of Zimbabwe: Harare, Zimbabwe, 1999; Volume 116.

135. Arhem, K. Maasai food symbolism: The cultural connotations of milk, meat, and blood in the pastoral Maasai diet. Anthropos 1989, 84, 1-23.

136. Riang'a, R.M.; Broerse, J.; Nangulu, A.K. Food beliefs and practices among the Kalenjin pregnant women in rural Uasin Gishu County, Kenya. J. Ethnobiol. Ethnomed. 2017, 13, 29. [CrossRef]

137. Hall, S.J.G. Livestock biodiversity as interface between people, landscapes and nature. People Nat. 2019, 1, 284-290. [CrossRef]

138. Salami, S.A.; Luciano, G.; O'Grady, M.N.; Biondi, L.; Newbold, C.J.; Kerry, J.P.; Priolo, A. Sustainability of feeding plant by-products: A review of the implications for ruminant meat production. Anim. Feed Sci. Technol. 2019, 251, 37-55. [CrossRef]

139. Vignolio, O.R.; Fernández, O.N. Cattle dung as vector of spreading seeds of exotic species in the flooding Pampa Grasslands (Buenos Aires, Argentina). Ann. Bot. Fenn. 2010, 47, 14-22. [CrossRef]

140. Kerby, J.D.; Fuhlendorf, S.D.; Engle, D.M. Landscape heterogeneity and fire behavior: Scale-dependent feedback between fire and grazing processes. Landsc. Ecol. 2007, 22, 507-516. [CrossRef]

141. Dlamini, P.; Chaplot, V. The impact of land degradation on the quality of soils in a South African communal rangeland. In Land Degradation and Desertification-A Global Crisis; IntechOpen: London, UK, 2016; pp. 81-92. 
142. Kgosikoma, O.E.; Mojeremane, W.; Harvie, B. The impact of livestock grazing management systems on soil and vegetation characteristics across savanna ecosystems in Botswana. Afr. J. Range Forage Sci. 2015, 32, 271-278. [CrossRef]

143. Klumpp, K.; Fontaine, S.; Attard, E.; Le Roux, X.; Gleixner, G.; Soussana, J.F. Grazing triggers soil carbon loss by altering plant roots and their control on soil microbial community. J. Ecol. 2009, 97, 876-885. [CrossRef]

144. Herrero, M.; Thornton, P.K.; Gerber, P.; Reid, R.S. Livestock, livelihoods and the environment: Understanding the trade-offs. Curr. Opin. Environ. Sustain. 2009, 1, 111-120. [CrossRef]

(C) 2020 by the authors. Licensee MDPI, Basel, Switzerland. This article is an open access article distributed under the terms and conditions of the Creative Commons Attribution (CC BY) license (http://creativecommons.org/licenses/by/4.0/). 